\title{
Philosophia Divitur: The Ecodiagrammatic Patterns of the Pierpont Morgan, M. 982 Leaf
}

\author{
James L. Smith
}

\begin{abstract}
This article explores the diagram found on the recto side of Pierpont Morgan, M. 982, a single leaf from a twelfth-century manuscript held by the Morgan Library and Museum in New York, and believed to originate in the scriptorium of Saint Peter's Abbey in Salzburg, Austria. The diagram represents knowledge as an 'ecodiagrammatic' pattern, depicting the relationship of hierarchical organisms through a fluid cascading system. Spanning riparian, fluvial, and corporeal symbolism, the diagram represents knowledge as a process of expanding categories from unitary source to manifold destinations. Furthermore, it demonstrates the ecological nature of typology, with multiple forms of ecological diagram merging to form a broad ontological pattern spanning metaphysical hierarchies.
\end{abstract}

Pierpont Morgan, M. 982 is a manuscript fragment held in the collection of the Morgan Library and Museum in New York, formerly known as the Pierpont Morgan Library. ${ }^{1}$ Within the intricate illustrations of its recto and verso, we are presented with a vision of the Seven Liberal Arts that mingles figurative human representation, a diagrammatic, abstract representation of knowledge as a river, and the personified agency of learning within medieval intellectual culture. Labelled within the library's collection as 'Philosophy nourishing the Liberal Arts, with Arithmetic, Astronomy, Music and a fourth art instructing', M. 982 is a single leaf excised from a larger manuscript. Described by its curators as an illustration in Romanesque style from the monastic scriptorium of St Peter's Abbey in Salzburg, Austria, the M. 982 leaf is thought to have been created during the second third of the twelfth century, c. $1133-1165 .{ }^{2}$ If this provenance is correct, M. 982 was the product of a wellestablished and influential node of manuscript production within the oldest

${ }^{1}$ Hereafter M. 982. All references to 'M. 982' pertain to the recto, unless specifically stated otherwise. This essay is a modified and expanded version of a chapter from my doctoral thesis, 'Water as Medieval Intellectual Entity: Case Studies in Twelfth-Century Western Monasticism' (unpublished PhD thesis, University of Western Australia, 2014). I would like to thank Parergon's anonymous referees and my thesis examiners, Ellen Arnold, Megan Cassidy-Welch, and Veronica Strang, for their feedback. Unless noted otherwise, all translations are my own.

${ }^{2}$ See Melanie Holcomb (with others), Pen and Parchment: Drawing in the Middle Ages (New Haven: Yale University Press/Metropolitan Museum of Art, 2009), pp. 98, 100. The most convincing hypothesis is that the leaf comes from St Peter's Abbey, Salzburg, the origin of a 
monastery of German-speaking Europe. ${ }^{3}$ There is much to recommend this intriguing piece of medieval visual culture beyond its artistry and beauty. Indeed, Eric Ramírez-Weaver has argued that the artistry of any medieval diagram is a fundamental component of its efficacy at 'the intersection of the demands placed upon [it] by both art and science' as a representation of the structural relationships between linked ideas, and not adornment alone. ${ }^{4}$

The recto of M. 982 depicts Lady Philosophy dominating the centre of the image, dressed in full queenly regalia. Above her crowned head are the stars in the firmament; in her hands are a sceptre of power and books of knowledge. From her heart pour seven streams of fluvial matter, forming a delta pattern as they diverge across the page. Below these streams are the personified Liberal Arts, each carrying the tools that identify them: a bowl for Grammar, a sword and shield for Rhetoric, a set square for Geometry, a harp for Music, and so on. ${ }^{5}$ Each of the Arts leans forward, drinking the liquid essence of Philosophy. Behind the scene rises a great wave, encapsulating all eight figures and bursting onto the page with a detailed illustration of motion (see Figure 1). On the verso of the document, the transmission of knowledge continues, moving from an aqueous representation of knowledge into a more interpersonal image of communication. On the top left of the leaf, Arithmetic displays her arts to a mathematician, who counts an equation with his fingers. To the right, an angelic representation of Astronomy points out and names the heavenly bodies, lecturing to a rapt audience (see Figure 2). Below and to the left is a music lesson, with the personified art teaching her pupil the subtleties of the lyre. To the right is a more ambiguous figure identified by curators as Medicine, mixing a remedy using herbs delivered by a satyr, which is possibly a representation of wild nature (see Figure 3). The leaf reveals an artistic and diagrammatic visualisation of knowledge that merges the systematic and material traits of water with the mediative functions of a human body. ${ }^{6}$

frontispiece of a very similar style and arrangement depicting St Rupert of Worms (the first Bishop of Salzburg) remaining in the collection of the Oesterreichische Nationalbibliothek.

${ }^{3}$ For more information on St Peter's Abbey and the manuscript production of medieval Salzburg, see the entry by Peter Dinzelbacher on Austria in William M. Johnston, ed., Encyclopedia of Monasticism (New York: Routledge, 2013), pp. 110-12.

${ }^{4}$ See Eric M. Ramírez-Weaver, 'William of Conches, Philosophical Continuous Narration, and the Limited Worlds of Medieval Diagrams', Studies in Iconography, 30 (2009), $1-41$ (pp. 3, 5).

${ }^{5}$ The identities of the figures in M. 982 are discussed in Laura Cleaver, 'Grammar and Her Children: Learning to Read in the Art of the Twelfth Century', Marginalia, 9 (2009), (unpaginated) para. 6-8. There is still a great deal of confusion as to the exact identity of some of the personified Arts. See also Holcomb (Pen and Parchment, p. 97), who describes identifying the iconography of M. 982 as 'an endless and frustrating game'.

${ }^{6}$ The circumstances by which the M. 982 leaf came to be divorced from its original manuscript are unknown. Its location and condition lead me to suspect excision for separate 


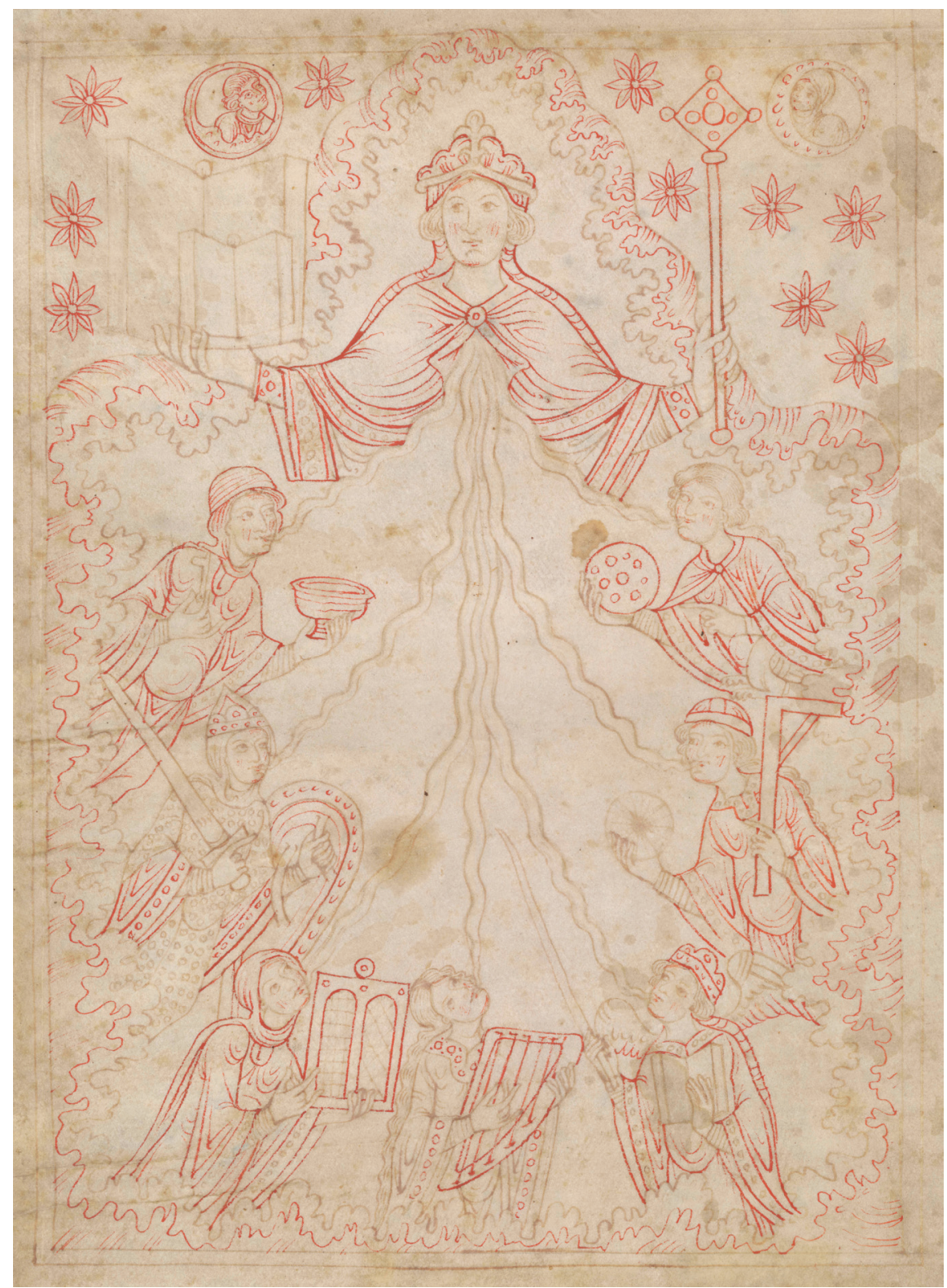

Figure 1

Philosophy nourishing the Seven Liberal Arts, with Arithmetic, Astronomy, Music and a fourth art instructing (Salzburg, Austria; second third of the twelfth century)

Source: New York, Pierpont Morgan, MS M. 982, single leaf, recto

Photographic credit: The Pierpont Morgan Library, New York. Purchased on the Belle da Costa Greene Fund, with special gifts of the Glazier Fund, Dr Ruth Nanda Anshen, Mrs Harold M. Landon, and Miss Julia P. Wightman, 1978. 


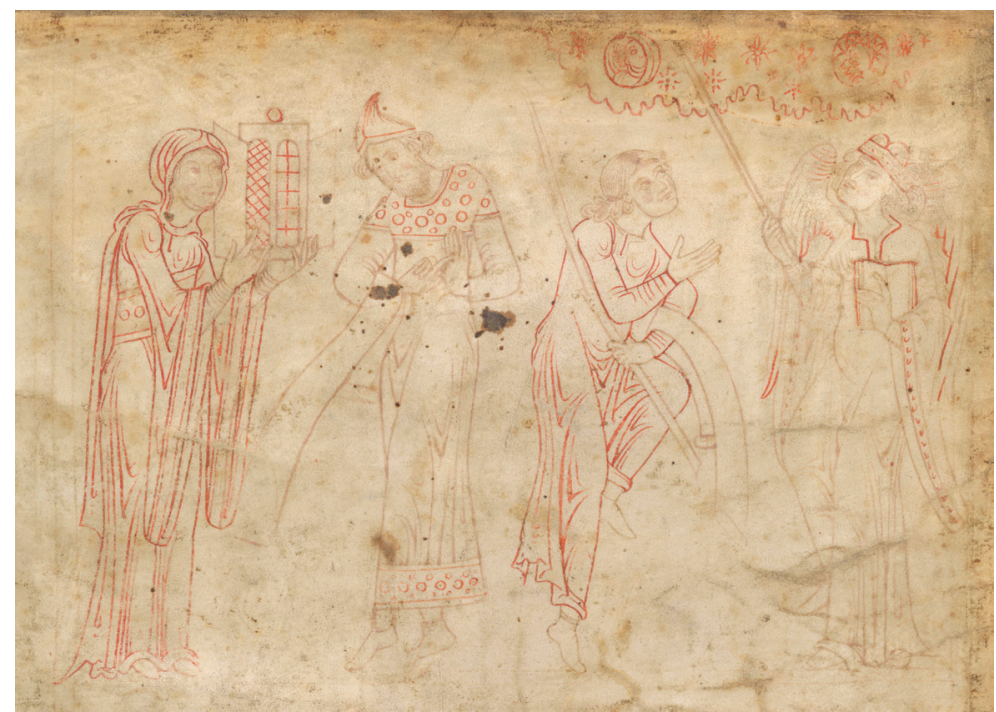

Figure 2

\section{Arithmetic and Astronomy}

Source: Pierpont Morgan, MS M. 982, single leaf, verso (upper half)

Photographic credit: The Pierpont Morgan Library, New York. Purchased on the Belle da Costa Greene Fund, with special gifts of the Glazier Fund, Dr Ruth Nanda Anshen, Mrs Harold M. Landon, and Miss Julia P. Wightman, 1978.

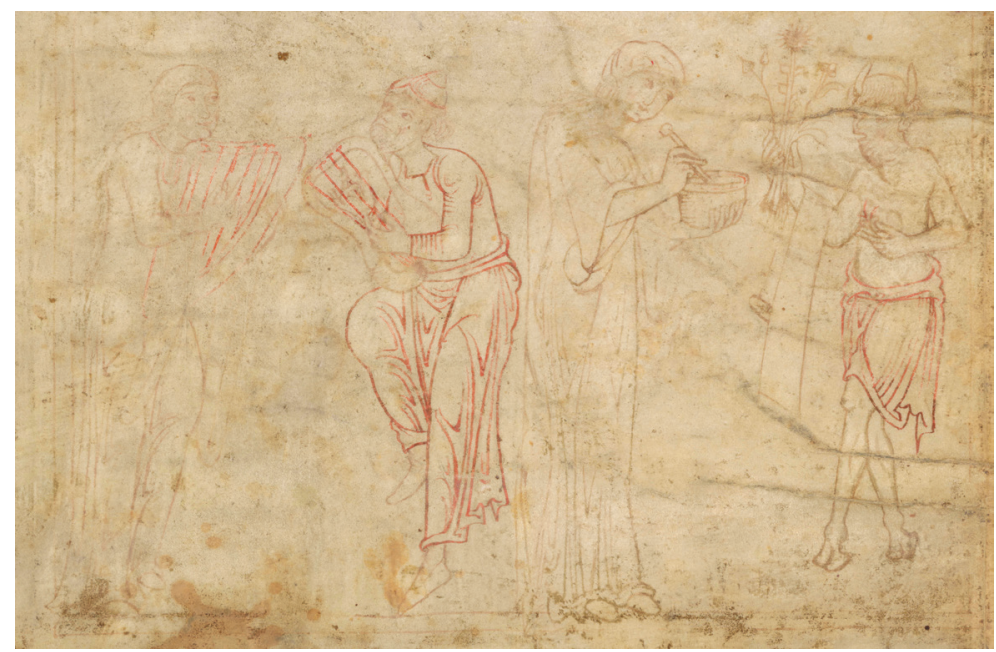

Figure 3

Music and a figure believed to represent Medicine

Source: Pierpont Morgan, MS M. 982, single leaf, verso (lower half)

Photographic credit: The Pierpont Morgan Library, New York. Purchased on the Belle da Costa Greene Fund, with special gifts of the Glazier Fund, Dr Ruth Nanda Anshen, Mrs Harold M. Landon, and Miss Julia P. Wightman, 1978. 
The leaf has probably been divorced from its original codex, thought to be either a manuscript of the De Consolatione Philosophiae of Boethius, the De Nuptiis Philologiae et Mercurii of Martianus Capella, or another unknown encyclopaedic volume. ${ }^{7}$ Of these three options, I propose that M. 982 is most convincingly matched to an encyclopaedia: its formal and contextual resemblance to diagrams found in contemporary texts such as the 1121 Lambert of Saint-Omer Liber Floridus provide a compelling link. During her discussion of encyclopaedic diagrams and their visual vocabulary, Anna Somfai characterises the high medieval encyclopaedic tradition as a reception and reproduction of late antique and early medieval diagrams together with a strong interest in the disciplines of the quadrivium. ${ }^{8}$ The additional images on the verso that visualise the transmission of the four scientific arts from their origin in the Trinity lend credence to the idea that M. 982 is an illustrative diagram from an encyclopaedia. The practice of the Sciences depicted on the verso of the leaf link to the recto's depiction of the Arts as an organic unity, demonstrating both the context of knowledge in the Liberal Arts and its application through the teaching of arithmetic, geometry, music, and astronomy. Furthermore, the combination of imitation and novelty found in many early twelfth-century encyclopaedic diagrams and an environment of 'intellectual inventiveness' provide a compelling historical context for M. $982 .{ }^{9}$

When M. 982 was selected by the New York Metropolitan Museum of Art to feature in an exhibit entitled Pen and Parchment: Drawing in the Middle Ages, the curator highlighted the fact that the image 'attests to both the learned concerns of medieval monastic audiences in the Salzburg region and to the iconographic innovations engendered by those interests'. ${ }^{10}$ It is in this context - namely, that the diagram is an artefact of monastic thought - that I will discuss M. 982: it was drawn by monastic scribes in order to illustrate points in a text of relevance to the educated and intellectual realm

sale, but it is not reasonable to do more than speculate.

${ }^{7}$ See the leaf's entry (s.v. 'M.0982v') in the Morgan Library's CORSAIR Collection Catalogue <http://corsair.themorgan.org>; see also Holcomb, Pen and Parchment, p. 98.

${ }^{8}$ Anna Somfai, 'The Liber Floridus in the Encyclopaedic Tradition: Philosophical and Scientific Diagrams in Context', in Liber Floridus 1121: The World in a Book, eds Karen de Coene, Martine de Reu, and Philippe de Maeyer (Tielt: Lannoo, 2011), pp. 75-89 (p. 76). The diagrams appear in addition to information about cosmology and the computus diagrams used for calculating liturgical dates.

${ }^{9}$ Somfai, p. 88.

${ }^{10}$ See the description of M. 982 (Related Images: 'Philosophy and the Seven Liberal Arts') via the Metropolitan Museum of Art's blog post related to the exhibition, 'Drawing and the Learned Tradition' <http://blog.metmuseum.org/penandparchment/drawing-andthe-learned-tradition/>; see also (the accompanying volume for the exhibition) Holcomb, Pen and Parchment, pp. 97-100 (quote at p. 97). 
of monastic thought. In addition to its didactic qualities, the recto of M. 982 is 'ecodiagrammatic', a term that I deploy here to refer to the expression of divine and environmental ecology through the structural conceits and techniques of medieval knowledge visualisation. ${ }^{11}$

The uncertain provenance and reception of the manuscript must be acknowledged as a limitation to our understanding of its meaning; RamírezWeaver describes the 'continuous narration' role of diagrams, interacting with, enhancing, and sometimes even contradicting their accompanying text as its ideas progress. ${ }^{12}$ Since we are unable to pin down the exact manuscript context of the diagram, we cannot fully understand it if we approach it simply as an artefact of art history or the history of science; I will instead explore M. 982 as a structural and diagrammatic collection of contemporary visual tropes linked to the visual representation of knowledge and its transmission, a different form of diagrammatic context. The M. 982 diagram functions independently of its context as a representation of medieval thought; not only as an expression of allegorical art, but also as a systematic arrangement of knowledge for the edification of the viewer. It has the ability to be selfcontained, linking to other diagrams through a shared tradition of knowledge visualisation, rather than by a manuscript tradition. By analysing the mixture of ecological patterning that it represents, this article demonstrates the manner in which medieval - and specifically twelfth-century - composition reduplicated structures of interconnection, based upon the fluid patterns of a riparian cascade and present at multiple metaphysical levels, which are described below as ecodiagrammatic flows. None of these structures is mutually exclusive, for the medieval tendency towards polyvalent reading ensured that layering was cumulative, and meaning was greater than the sum of any parts.

\section{Visualising Ecodiagrammatic Flows}

The recto image of M. 982 participates in a tradition of 'complex "visually exegetical" schemata' that were becoming increasingly popular in the twelfth century, and the verso image demonstrates the interactions engendered by such a schema. ${ }^{13}$ The goal of images derived from this tradition, in the words of Annette Krüger and Gabrielle Runge, was to 'demonstrate

${ }^{11}$ I define 'ecodiagrammatology' as the study of symbolic representations of the relations of (abstract or material) organisms to one another according to a shared (in this case medieval) visualisation technique.

${ }^{12}$ Ramírez-Weaver, 'William of Conches', p. 1.

${ }^{13}$ Annette Krüger and Gabrielle Runge, 'Lifting the Veil: Two Typological Diagrams in the Hortus deliciarum', Journal of the Warburg and Courtauld Institutes, 60 (1997), 1-22 (p. 2). 
the relationships between parts of a theoretical system by means of the geometrical organisation and correlation of pictorial and textual elements', providing a complex schema for interpretation by those with the knowledge to read it. ${ }^{14}$ It emerged as part of a burgeoning diagrammatic trend: Franz Saxl argued that 'the 12th century did not invent the idea of representing a group of notions in diagrammatic form; but it was not until then that this device played so considerable a part'.$^{15}$ The arrangement of the elements in such a diagram was topological, requiring accuracy of contiguity rather than of mathematical scale, angle, size, or shape. ${ }^{16}$ It was a mapping of relationship, of the connection of a thing to all other things through elaborate multiform pathways. ${ }^{17}$ Rather than attempting to pin down the iconographic definition of the contents within the leaf, my goal here is to focus on the form, the arrangement, of the diagram. The exact contents of M. 982 are difficult to identify, and yet the systematic logic of the image offers an excellent subject of study.

The images found on the single leaf of M. 982 connect the realm of the visual with the realm of the abstract, illuminating the ecosemiotic relationships between entities. ${ }^{18}$ The visual accessibility of the images presents the ideal passage into analysis, for their creator(s) chose to provide these diagrams to the readers of the now unknown codex so that the book's complexities might be better apprehended. It is abstract, because the resulting image visually signifies not only an arrangement of aesthetic and narrative values, but also signifies an embedded infrastructure of invisible ideas; these ideas flow between the divisions of learning, and they flow from the source into the manifold disciplines of the Liberal Arts. It displays many similarities to another image of the Seven Liberal Arts found in the Hortus Deliciarum of Herrad of Landsberg, suggesting that the motif it displays, although arranged differently in many diverse contexts, was a relatively common representation

${ }^{14}$ Krüger and Runge, p. 2.

${ }^{15}$ Franz Saxl, 'A Spiritual Encyclopaedia of the Later Middle Ages', Journal of the Warburg and Courtauld Institutes, 5 (1942), 82-142 (p. 107).

${ }^{16}$ Catherine Delano-Smith, 'Maps and Plans in Medieval Exegesis: Richard of St. Victor's In visionem Ezechielis', in From Knowledge to Beatitude: St.Victor, Twelfth-Century Scholars, and Beyond. Essays in Honour of Grover A. Zinn Jr., eds E. Ann Matter and Lesley Smith (Notre Dame: University of Notre Dame Press, 2013), pp. 1-45 (p. 3).

${ }^{17}$ For a new and comprehensive collection of essays, see Emily Steiner and Lynn Ransom, eds, Taxonomies of Knowledge: Information and Order in Medieval Manuscripts (Philadelphia: University of Pennsylvania Press, 2015).

${ }^{18}$ For a strong introduction to premodern ecosemiotics, see Alfred Siewers, 'PreModern Ecosemiotics: The Green World as Literary Ecology', in The Space of Culture: The Place of Nature in Estonia and Beyond, ed. Tiina Peil (Tartu: Tartu University Press, 2011), pp. 39-68 (p. 41). 
of twelfth-century knowledge theory. ${ }^{19}$ The hydrological imagery of the diagram flows from a powerful ecodiagrammatic stream of precedent found within inchoate twelfth-century practices of knowledge visualisation arising from the mnemonic-ekphrastic practices of monastic thinkers. ${ }^{20}$ The rhetorical register is broad, and key themes include the imagery of Revelation (the tree of life, the rivers of paradise); the description of Scripture as a source of nourishment and refreshment; and a topographical theme of riparian structure attached to the divisiones of multipartite entities such as the senses of Scripture, sacred science, and the Liberal Arts. ${ }^{21} \mathrm{~A}$ particularly interesting and well-developed example appears in Godfrey of Saint-Victor's Fons Philosophiae, a twelfth-century Latin poem visualising the didactic structure of Hugh of Saint-Victor's Didascalicon - itself, a treatise delineating the Seven Liberal Arts - as a river system, complete with fountainhead, branches, local conditions, and material properties. ${ }^{22}$ In this tradition, didactic knowledge transmission draws on Scriptural and ecological imagery to provide a framework for learning. ${ }^{23}$ The M. 982 imagery is a distinct reworking of a diagrammatic convention popular throughout the Middle Ages and into modernity: the tree. ${ }^{24}$

The tradition of a branch representation can be seen in two images of the Liberal Arts in which we apprehend a structural trope sans water, and yet in a cognate arrangement (see Figures $4 \mathrm{a}$ and $4 \mathrm{~b}$ ). These two diagrams both demonstrate the conventionality of a branch structure, revealing the manner

${ }^{19}$ A point strengthened, in the case of the Hortus Deliciarum, by context. The Hortus was created as a pedagogical tool for novices, and is thought to have been a compendium of twelfth-century knowledge with deluxe illumination rather than a wholly original text.

${ }^{20}$ Discussed comprehensively in Mary Carruthers, The Craft of Thought: Meditation, Rhetoric, and the Making of Images, 400-1200 (Cambridge: Cambridge University Press, 2000). For an early modern continuation, see Lina Bolzoni, The Gallery of Memory: Literary and Iconographic Models in the Age of the Printing Press, trans. Jeremy Parzen (Toronto: University of Toronto Press, 2001).

${ }^{21}$ To apprehend the depth of these links, see Henri de Lubac, Medieval Exegesis: The Four Senses of Scripture, 2 vols (London: Continuum, 2000), I.

${ }^{22}$ For more historical context and a discussion of late antique and early medieval reception, see Smith, 'Water as Medieval Intellectual Entity', esp. chap. 2, 'The Medieval Properties of Water Metaphor', pp. 35-60, and chap. 4, 'Godfrey of Saint-Victor's Fons Philosophiae and the Riparian Liberal Arts', pp. 87-112.

${ }^{23}$ For more on the functioning of twelfth-century knowledge visualisation, see in particular Mary Carruthers, 'Moving Images in the Mind's Eye', in The Mind's Eye: Art and Theological Argument in the Middle Ages, eds Jeffrey J. Hamburger and Anne-Marie Bouché (Princeton: Princeton University Press, 2006), pp. 287-305.

${ }^{24}$ For a survey of medieval tree motifs, see Pippa Salonius and Andrea Worm, eds, The Tree: Symbol, Allegory, and Mnemonic Device in Medieval Art and Thought (Turnhout: Brepols, 2014); and the discussion of the Arbor scientiae in Mary Franklin-Brown, Reading the World: Encyclopedic Writing in the Scholastic Age (Chicago: University of Chicago Press, 2012), pp. $129-82$. 
in which philosophy is provided and divided. The earlier image, taken from a ninth-century copy of Cassiodorus's Institutiones, bears the title philosophia dividitur (philosophy is divided), and illustrates the categories of learning through a decorated diagram. ${ }^{25}$ The second, taken from a twelfth-century theological miscellany, is plainer in style and yet more complex in its vision of philosophy. Taken together, these diagrams demonstrate a long tradition of such representations inherited from late antiquity and the early Middle Ages, and in a state of continual reproduction and adaptation in the twelfth century. The diagrammatic traditions of Cassiodorus, for example, were transmitted and re-adapted throughout the Middle Ages, and M. 982 represents premedieval ideas in a novel arrangement: a new gloss on an old structure. They support the assertion of Ramírez-Weaver and Somfai that diagrams exist in an environment in which the inventiveness of the scribe brings new meaning to old patterns. ${ }^{26}$ In the case of BL, MS Royal 7 D II, fol. 9v, the invention was to add more information but to leave the artistic structure relatively unchanged. In the case of M. 982, the invention was artistic and hydrological in nature. A middle point between these two diagrams and M. 982 is hinted at in the commentary appearing on either side of the seated Lady Philosophia in the Hortus Deliciarum diagram: 'Seven sources (fonts) flow forth from Philosophy, which are called the Liberal Arts. The Holy Spirit is the author (inventor) of the Seven Liberal Arts, which are grammar, rhetoric, dialectic, music, arithmetic, geometry, and astronomy.' The image demonstrates the lines of force that united the parts of Liberal Arts knowledge into a machine for vital and lively spiritual life through learning; a transfer from inventor to human practitioner. The passage above demonstrates the step between the need to visualise Philosophy, and the need to enliven it with allusion to a series of flows. The process of monastic learning was both organised techne (craft) and cursus (course), and thus required a form of intellectual and spiritual induction to guide the mind onto the path to Christ. ${ }^{27}$ This path, as Mette Bruun explores, 'connotes a transversibility of the otherwise absolute

${ }^{25}$ A phrase repeated in the top left of the Liberal Arts diagram in the Hortus Deliciarum: 'Philosophia dividitur in tres partes, que sunt ethica, logica, [et] physica'. These three parts are represented by three heads upon the crown of Philosophia, who in turn pours forth the stream of the trivium on the right and quadrivium on the left. Below the throne, Socrates and Plato sit writing under her inspiration, surrounded by the personifications of the Seven. Outside of the circle of the Arts, poets and magi sit inspired by impure spirits ('immundis spiritibus').

${ }^{26}$ See Michael Gorman, 'The Diagrams in the Oldest Manuscripts of Cassiodorus' Institutiones', Revue Bénédictine, 110 (2000), 27-41. In the case of Cassiodorus's Institutiones, the importance of the diagrams was long overlooked by scholars despite their importance as a major innovation in the history of the book, and their reception in later work.

${ }^{27}$ Karl F. Morrison, 'Incentives for Studying the Liberal Arts', in The Seven Liberal Arts in the Middle Ages, ed. David L. Wagner (Bloomington: Indiana University Press, 1983), pp. 
demarcation between heaven and earth, between "heres" and "theres"' ${ }^{28}$ Through the figure of Philosophy as a human woman, but simultaneously as a Marian fountainhead and a mediator of diverse branching paths, we gain both an image of the here denoted by the Seven Arts, and the there implied by the figure of Philosophia.

The evocation of the Seven Arts as rivers follows a self-consciously riparian evocation of structure immediately followed by a list of branches. ${ }^{29}$ M. 982 moves beyond the structural tropes of other diagrams within its genre by visually representing the flows. The trope of river survey as exposition of knowledge taxonomy occurs in many places throughout this article, and provides insight into what I will term the diagrammatic dimension not only of M. 982, but of hydrological abstraction as a whole. The functioning of medieval visual culture, combined with the techniques of the ars memoriae practitioner, gave power to the structural logic of water. Water functioned in all three of the traditions identified by Mary Carruthers as the medieval art of graphical composition within the mind's eye: ekphrasis (composition); the view from above (known as the kataskopic view); and previsualisation. ${ }^{30}$ Put more simply, the use of a riverine structure has unique affordances in the narration of a story detailing the relationship between esoteric and invisible principles, for it is an entity that composes images with a spatial overview effect - such as that which modern people might gain by viewing the earth from an aeroplane, or from space - allowing structural previsualisation. The paths followed by the practice of the Arts allowed small glimpses into the overall layout of these realms, a distant reading of knowledge arrangement. ${ }^{31}$

The network, rather than simply raising questions, attempts to provide a structure of transfers, relations, and movements that provides, if not the answers to the questions, then the framework for answering them in context. Water may appear to be both a close-up image, and a set of systematic traits, observable only at a distance. Diagrams provide structural insight, but at the

32-67 (p. 32): 'The term ars is the Latin equivalent of the Greek techne - a systematic and complete body of knowledge deriving from a clear beginning point (or principle).'

${ }^{28}$ Mette B. Bruun, Parables: Bernard of Clairvaux's Mapping of Spiritual Topography (Leiden: Brill, 2007), p. 98.

${ }^{29}$ The single copy of the Hortus Deliciarum, although destroyed in 1870 - along with the Strasbourg library in which it was housed - was meticulously reconstructed in Rosalie Green, ed., Hortus Deliciarum: Manuscript Reconstruction w. Commentary (London: Studies of the Warburg Institute, 1979).

${ }^{30}$ Carruthers, 'Moving Images', p. 302; for further discussion of this point, see Smith, 'Water as Medieval Intellectual Entity', pp. 53-54.

${ }^{31}$ For a discussion of the much more ambitious knowledge visualisation of Hugh of Saint-Victor's Mystic Ark diagram, see Conrad Rudolph, 'First, I find the Center Point': Reading the Text of Hugh of Saint Victor's 'The Mystic Ark' (Philadelphia: American Philosophical Society, 2004). 
expense of detail. They do, however, offer an insight into an entirely different scale of detail. Examples from natural processes, as understood through observation, offer a template for mimesis within the landscape of abstract expression. Take the example of the cascading system:

Cascading systems are composed of connected chains of subsystems, through and between which may flow a cascade of mass or energy. Thus the output from one subsystem may, in whole or part, become the input for another, perhaps triggering off threshold reactions or complex resonances in the latter. ${ }^{32}$

In the case of M. 982, we see a simplified visualisation of many systems and subsystems, from One, to Trinity, to Theology, to Arts, to human life, and then onwards further still; we are presented with a simple allegory denoting a complex unfurling of effects. Outputs become inputs, for just as God engenders Philosophy, so too does Philosophy enter the Arts, which in turn enter human life. The divine harmony of the spheres becomes the proportion and tone of music, which in turn becomes the personified allegory of music, which all leads to the playing of a lyre. Through the outpouring and simultaneous division of categories in the form of streams, the knowledge essence of the cascade engenders new effects, providing the impetus for a new stratum of interactions. This notion, taken from systems theory, provides a satisfying link to the medieval chain of being and to the Seven Liberal Arts that serve as the ancestor of modern scientific disciplinary arrangement. M. 982 represents the resonances between the divisiones philosophiae, the categories of the Arts, and the cascading of a riverine network.

The nature of metaphysics within medieval thought, be it Platonic or Aristotelian, was bound up in gradations, hierarchies, and categories. That which differentiated human from beast, animate from inanimate, lofty from lowly, retained coherence only through strict categorisation. The reality of the cosmic gradation might demonstrate to us that these categories were actually blurred and confused, and yet categorisation provided a comforting schema for classification in an intellectual realm in which these ambiguities were less pronounced. The combination of rigid and ambiguous offered by the image of a river seems, to my mind, highly appropriate and structurally eloquent.

When viewed as a diagram, M. 982 shares many traits with a broader collection of twelfth-century representations of knowledge. Unlike many of these images - the Liberal Arts schema from the Hortus Deliciarum, for example - it eschews the concisely arranged circles and arcs of sacred

32 Richard J. Chorley, Stanley A. Schumm, and David E. Sugden, Geomorphology (Cambridge: Cambridge University Press, 1984), p. 43. 
geometry for a rougher, vaguer, more artistic hermeneutic framework. Yet, as is the case with any image found within a medieval manuscript, it is far more than decoration alone. M. 982 retains a diagrammatic dimension in the absence of strict geometric rules governing meaning like many of its fellows. This is possible by virtue of a 'fuzzy logic' gifted to it by the flexible structure of hydrology. When grafted upon a framework of Liberal Arts interrelation, the aqueous register of the image lends a powerful intuitive edge, a holism, and yet also an internal self-classification.

\section{Prosopopoeia}

The majestic form of Philosophia, female avatar of organised knowledge, is best known from her depiction in the De Consolatione Philosophiae of Boethius. As voice of authority and guide to Boethius in his quest for truth in the face of imminent execution, the Lady has found her way into the very core of epistemic symbolism commonly associated with medieval philosophy. ${ }^{33}$ Together with the fickle Lady Fortuna and her rota fortunae (wheel of fortune), Philosophia is one of Boethius's most famous creations. ${ }^{34}$ In the Consolatione, her majestic form fills the prison cell of the soon-to-die narrator, impressing her power upon him:

While I was quietly thinking [despairing] thoughts over to myself and giving vent to my sorrow with the help of my pen, I became aware of a woman standing over me. She was of awe-inspiring appearance, her eyes burning and keen beyond the usual power of men. ${ }^{35}$

As Boethius sees the form of the Lady, what are the implications of her bodily distillation of pure knowledge and learning? What does it mean to give human face to an inhuman thing? ${ }^{36}$ The use of figurative imagery brings a subtle and powerful valence to the complexity of non-human interconnectivity. ${ }^{37}$ In a

${ }^{33}$ The ubiquity of Lady Philosophia is partially responsible for the efficacy of the M. 982 diagram. As a symbolic commonplace, the manner in which Philosophia is presented draws attention to any novelties of representation, in this case the fluvial structure of M. 982.

${ }^{34}$ Although neither figure is original in itself, they are nevertheless part of a long history of classical and late antique reception and adaptation. Philosophia and Fortuna both have deep roots in the Classical tradition.

${ }^{35}$ Boethius, The Consolation of Philosophy, trans. Victor Watts (London: Penguin Books, 1999), 1.1 (pp. 3-4).

${ }^{36}$ I am indebted to Julie Orlemanski for posing this question as part of her talk 'Things without Faces' in the Objects, Networks, and Materiality roundtable organised by the George Washington Medieval and Early Modern Studies Institute at the 2011 Kalamazoo Congress of Medieval Studies. Her work on the project continues under the provisional title 'Things without Faces: Remediation and Medieval Allegory'.

${ }^{37}$ C. M. Kauffmann, A Survey of Manuscripts Illuminated in the British Isles, Vol. III: Romanesque Manuscripts 1066-1190 (London: Harvey Miller, 1975), ill. 50, p. 62. It is 
medieval context, we can see the personification as a form of integumentum, an outer layer hiding a divine mystery. Peter Dronke has discussed this phenomenon in the context of twelfth-century poetics in his work on the fabula, interpreting the veiling of meaning in a personification allegory as a form of both protecting and embellishing truth with 'beauty and dignity'. ${ }^{38}$ As Macrobius put it in his late antique Commentary on the Dream of Scipio, '[wise men] know that Nature loathes an open, naked exposition of herself'. ${ }^{39}$ Drawing on the tradition of veiling deeper mysteries in accessible allegories, the form of Lady Philosophia and the network of the Arts points to an unknowable and hidden cosmic structure presented through mythical figures, just as the pagan gods of old were interpreted by mythographers and exegetes as the outer facets of a fundamental force or principle. The various meanings found within the diagram - both structural and figurative - were parts of a multivalent outer layer hiding and yet enabling endless divine mysteries.

The cipher of the human form could contain a mythical goddess, a series of iconographic components (crown, sceptre, and books), a river, the pattern of the Liberal Arts, the transfer of knowledge, and the metaphysical order of the Cosmos. ${ }^{40}$ The greater order was reduced in microcosm and presented through a veiling iconographic allegory. By giving bodily form to philosophy, the process of mediation merges with that of the aqueous medium to combine human agency and the distributive power of a river system. The flow of knowledge is then 'imbibed' by means of the 'mouths' of the Liberal Arts, each given a form appropriate to its role. Behind the speaking and expressive façade of a living countenance lies a world of invisible abstractions given form, character, and the power of speech through allegory of personification. The Rhetorica Ad Herennium describes the technique of prosopopoeia that enables this process, as follows:

interesting to note that similar iconography of Ecclesia appears in an 1120, Canterburyproduced, Romanesque-style image of Augustine's City of God (Florence, Biblioteca Mediceo-Laurenziana, MS Plut. XII, fol. $2^{v}$ ). In this image, the personified queenly figure of the Church appears with crown, sceptre, and book, surrounded by stars. This image features an angel guarding four rivers pouring from the bottom of the city.

${ }^{38}$ Peter Dronke, Fabula: Exploration into the Uses of Myth in Medieval Platonism (Leiden: Brill, 1974), p. 55. The fabula is discussed by Dronke in the context of William of Conches and the reception of Macrobius.

${ }^{39}$ Dronke, p. 47, citing Macrobius's Commentary on the Dream of Scipio (I.2.17).

${ }^{40}$ For an intriguing discussion of the multiple levels upon which a personified force could operate in medieval interpretation, see Jane Chance, Medieval Mythography, 2 vols (Gainesville: University Press of Florida, 1994), I: From Roman North Africa to the School of Chartres, AD 433-1177, pp. 6-10. Chance discusses Eridanus, who was image, myth, icon, river, star constellation, and text in antique sources in equal measure. See also vol. II, which covers the later twelfth century and up to the end of the medieval period. 
Personification consists in representing an absent person as present, or in making a mute thing or one lacking form articulate, and attributing to it a definite form and a language or a certain behaviour appropriate to its character ... Personification may be applied to a variety of things, mute and inanimate. ${ }^{41}$

The blending of prosopopoeia and aqueous abstraction within M. 982 is a particularly powerful technique; it merges the power of the human form to represent the abstract principles, intention, and mediation behind knowledge with the material and connective force of water. Lady Philosophy participates in a series of encapsulations and typological resemblances. These exist simultaneously as part of a complex and polyvalent ecological pattern, merging diverging visual registers and functioning as a complex allegorical mechanism for the edification of the reader.

Mary, whom Philosophia resembles through iconography and gender symbolism, bore the infant Christ in her womb; Christ in turn bore the sins of the world in his death, the divine Logos in his speech, and the superlative form of humanity in his role as Saviour. The Garden of Eden was womb to Adam and Eve, the source of its rivers womb to the waters of the world. Mary is associated with the fountain of spiritual grace, as is Christ. In many images of the Crucifixion, angels stand by to catch the salvific flow of bloodand-water from the side of Christ, and so too do the Arts wait to catch the outpouring essence of the Lady distilled into a pure flow of learning. Through an assemblage of diverse connotations, Philosophia brings a human face to the myriad generative principles of Creation. Water, as the mediator of this source, represents both the undifferentiated source of a hidden reservoir (the great wave behind the image) and the pouring forth of essence.

To return to the diagrammatic dimension for a moment, let us consider the role of the human body (or indeed the non-human body) in the construction of meaning. In the passage below, Sybille Krämer proposes that the process of creating a diagram provides a conduit by which the hidden universals of our world become intuitively 'available' to our senses. They are cloaked, so to speak, in an integument of aesthetic experience:

Diagrammatic inscriptions, among which we include graphic artefacts ranging from notations to diagrams to maps, are media that provide a point of linkage between thinking and intuiting, between the "noetic" and the "aesthetic". By means of this interstitial graphic world, the universal becomes intuitable to the senses and the conceptual becomes embodied. ${ }^{42}$

${ }^{41}$ Rhetorica Ad Herennium, ed. Harry Caplan (London: Heinemann, 1954), p. 399 (IV:66-LIII).

${ }^{42}$ Sybille Krämer, 'Epistemology of the Line: Reflections on the Diagrammatic Mind', in Studies in Diagrammatology and Diagram Praxis, eds Olga Pombo and Alexander Gerner 
Through the embodiment of thought, achieved by visual and diagrammatic representation, 'the difference between the perceptible and the intelligible [in diagrams] is thus at the same time bridged - and constituted' ${ }^{43}$ The non-human body of the hydrological allegory and the human body of the personification allegory merge to create a space for the flow of understanding to pour between the unyielding surface of abstraction and the channels by which phenomenal meaning is made. At the same time, the hidden origin of knowledge remains invisible, behind the frame of personhood presented by Philosophia. Just as the walled inaccessibility of Eden is bridged by the ecumenical connection of water, so too is knowledge rendered invisible and yet present in the personhood of its avatar.

Within this process, water is the moving, shifting transfer between minds, representing the tree of knowledge in the most effective expression of human (or human-like through allegory) and non-figurative tangibility. The technique of personification allegory lends, as James Paxson claims, 'a figural manoeuvre distinct from lending "a definite form" to something without physical contour, something insubstantial'. ${ }^{44}$ The aqueous component of the image lends a flexible and non-definitive form, giving an apprehensible reality to an invisible process of intellectual transfer on a metaphysical scale. Human behaviour mapped over inhuman forces merges the affective power of the body with the inhuman affective force of the material world apparent within water. Through the merging of two forms of substance, the allegory is enabled on a double level. ${ }^{45}$

To place this process into a broader context, let us consider the image of Christ in Majesty found within the thirteenth-century Westminster psalter map (see Figure 5). Within this famous mappa mundi, the representation of Christ expresses a similar sentiment to the following passage from Thomas Aquinas's commentary on the Gospel of John, in which a similar outpouring is implied:

[I]t is of the same manner of speaking, just as if someone taking up water from the river were to say: "this water is not of the river, but is of the fountain: indeed it is not the origin of the river," and so on. Thus, the Lord says "whoever believes in me, does not believe in me, but in him who sent

(London: College Publications, 2010), pp. 13-38 (p. 13; emphasis added).

${ }^{43}$ Krämer, p. 13.

${ }^{44}$ James J. Paxson, The Poetics of Personification (Cambridge: Cambridge University Press, 1994), p. 14.

${ }^{45}$ This enables what Stacy Alaimo (Bodily Natures: Science, Environment, and the Material Self (Bloomington: Indiana University Press, 2010), esp. p. 11) has termed 'trans-corporeality' the interfusion of human and environmental bodies - in the realm of allegory, and through a uniquely medieval articulation. 
me"; as if he says: "I am not the beginning in and of myself, but divinity is mine from another, that is, from the Father: and so he who believes in me, does not believe in me, except in as much as that I am from the Father." ${ }^{36}$

As is the case with Lady Philosophy, Christ is but an expression of a hidden river source, an outpouring of wisdom from the Father. Thus, like the Gospels, this knowledge network allows the approach of divinity through the apprehension of the intermediate links. These intermediaries are not true Theology, and yet through their hydrology they show their fons et origo (source and origin) (see Christ pantocrator in Figure 5). What would otherwise be obtuse is shown to be a path to a higher origin. There is evidence from other twelfth-century sources and the literature of preceding centuries that the trope of 'drinking' from the 'streams' of the Liberal Arts was a common one. The act of drinking, of imbibing sustenance, is redolent of the biblical link between the drawing of pure waters and the foretaste of divinity to be found within the stirrings of the Holy Spirit and the exemplum of Christ. To drink is to sample a taste of the divine, the filling of an empty vessel with pious plenitude. And yet it is also a thirst for a more intellectual form of knowledge wedded to this religious devotion in an intermingled union. The iconographic representation of a flow from invisible to visible resembles the imagery of Revelation, in which the stream of salvation from the throne of Christ spreads across the tree of life, engendering fruit 'for the healing of nations' . ${ }^{47}$

The overtly gendered implications of M. 982 need not be read as a single meaning alone; indeed, it would diminish the power of the image to do so. In an interesting twist - be it unintentional or deliberate - the lines of the Lady's cloak meet at her breast at the point of her brooch, circular and set with a stone. The brooch bears a striking similarity to the image of Eden at the apex of many mappae mundi, representing the locus that 'pins' the heavenly and worldly together. The streams of knowledge, like the spreading of the gospels and the flowing of the rivers, peregrinate to all corners of the image, ending in the act of consumption by the Arts.

The word 'nourishment' provides an interesting entry point into the image, for the most obvious interpretation of the streams of matter pouring from the chest of Lady Philosophy into the waiting mouths of the personified

46 Thomas Aquinas, Super Euangelium Iohannis reportatio, in Library of Latin Texts Series A (Turnhout: Brepols, 2015) (subscription-only, online edn via BREPOLiS < http://www. brepolis.net/>), caput 12, lectio 8, numerus 1711, linea 30 (pag. 319): 'Et est similis modus loquendi, sicut si aliquis hauriens de aqua fluminis dicat: ista aqua non est fluminis, sed est fontis: non est quidem fluminis originalis etc. Sic ergo dominus dicit qui credit in me, non credit in me, sed in eum qui misit me; quasi dicat: non sum principium mei ipsius, sed divinitas est mihi ab alio, id est a patre: unde qui credit in me, non credit in me, nisi in quantum sum a patre.'

${ }^{47}$ Cf. Revelation 22. 1-2. 

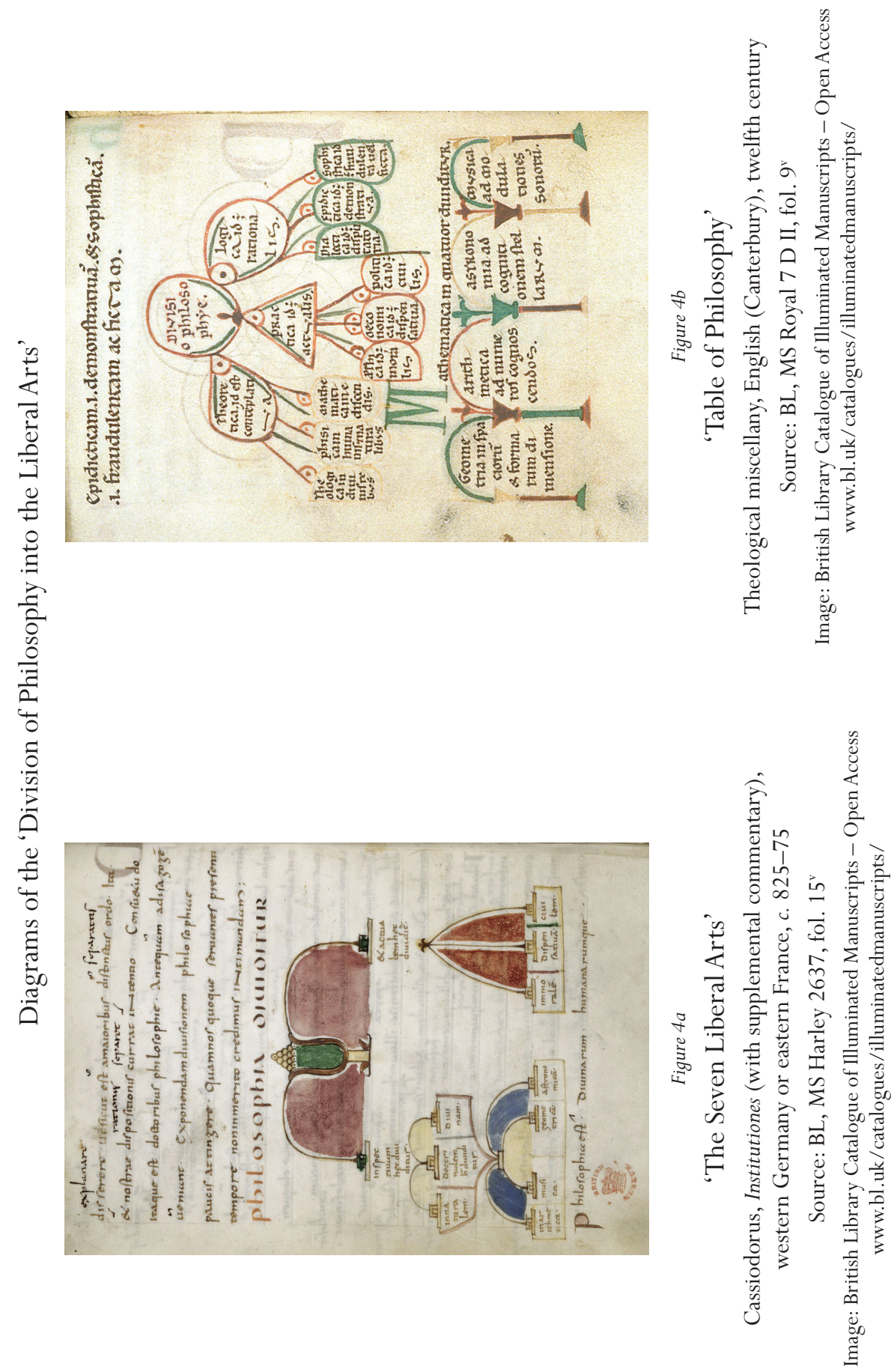


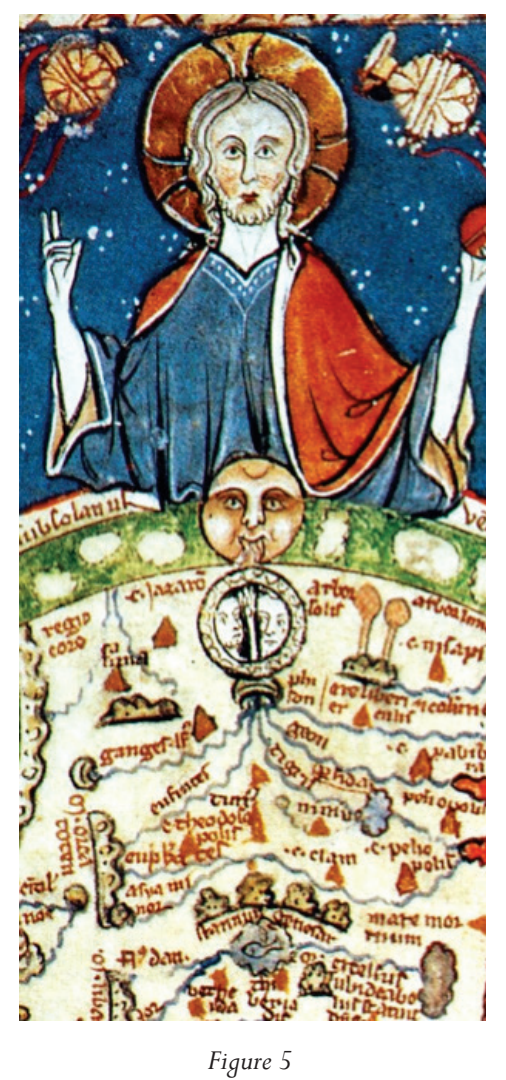

Christ in Majesty and the Rivers of Paradise

The Westminster Psalter mappa mundi, c. 1265

Source: BL, MS Add. 28681, fol. $9^{r}$

(C) The British Library Board 
Liberal Arts evokes the image of breastfeeding. Through the image of a human body, we see the principle of mediation and distribution, a kind of non-human agency, through the image of the Lady. Her intellect, the will behind the distributive power of knowledge, personifies the division of the fons. Flowing forth from her breast - an image of spiritual or motherly nourishment, or preferably a mixture of both - are the manifold nourishments of the Arts. She is alma mater, providing the sustenance of water's nutrition through an allegory of human intentionality. At the same time, she is the female body under a masculine intellectual schema, exhibiting both female generative power and the influence of a strict regime of structure and control. ${ }^{48}$ These lines resemble an umbilical cord, or a flow of milk, as much as they do a river or a flow of blood. The depiction of the Lady demonstrates a distinctly bodily resonance tied through similitude to the imagery of hydrology.

As Caroline Walker Bynum has demonstrated, images of motherly nourishment in the high Middle Ages could take forms within spiritual allegory that are highly unusual to modern sensibilities. ${ }^{49}$ Breast milk, for example, was held by contemporary natural philosophy to be processed blood. Just as the pelican, symbol of Christ, fed its young with the blood of its breast, so too did the mother rear her child from her very bodily matter. Blood, milk, and river all flowed from a hidden reservoir of energy, feeding the offspring, spiritual or physical alike. This imagery is typologically linked to the flow of blood from the five wounds of Christ at the Crucifixion. The chain of nourishment stretched from the Trinity: God created Adam, from whom Eve was created; and Mary was impregnated by divine power through immaculate conception, generating Christ as man from her bodily matter. Mary, as mediatrix of graces, was the conduit by which the power of the Son spread and divided among the followers of Christ. ${ }^{50}$

\section{Conclusion}

In his monograph, Visual Complexity, network visualisation theorist Manuel Lima proposes that the tree structure of premodern thought, no longer relevant to a modern world of endless interconnections, has given way to the

${ }^{48}$ For a detailed discussion of the transition from feminine imagery to masculine control in water imagery and its contraflows, see Veronica Strang, 'Lording it Over the Goddess: Water, Gender, and Human-Environmental Relations', Journal of Feminist Studies in Religion, 30.1 (2014), 83-107.

${ }^{49}$ Caroline Walker Bynum, Jesus as Mother: Studies in the Spirituality of the High Middle Ages (Berkeley: University of California Press, 1982).

${ }^{50}$ Bynum, pp. 132-33. 
structure of a web, or of a rhizome. ${ }^{51}$ Lima argues that " $[\mathrm{t}]$ he idea of capturing the entirety of human knowledge and classifying it by means of a tree is an aged aspiration, a meme hundreds of years old' ${ }^{52} \mathrm{~A}$ tree of knowledge is an excellent abstraction for the fixed and codified interrelationships of formal knowledge, and yet the structure of the tree is only a superficial pattern, a single manifestation of a deeper fluid network. ${ }^{53}$ Within this interpretation, the historical reality of medieval branch-like systems of abstraction is at risk of being occluded by the desire for new, more 'sophisticated', models. Lima, for example, citing Gilles Deleuze and Félix Guattari, claims that 'trees are a condition of theoretical rigidness and unidirectional progress, where everything returns to a central trunk through vertical and linear connections'. ${ }^{54}$ In the text itself, Deleuze and Guattari claim that the tree makes sense 'only if there is a strong principal unity available, that of the pivotal taproot supporting the secondary roots', and that this is a model that 'that doesn't get us very far'. ${ }^{55}$

Pierpont Morgan, M. 982 reveals the crucial importance of understanding the sophistication of medieval diagrams, their innovative nature, and their commodious incorporation of information. To neglect this task is to see the medieval diagram become a foil for modern sophistication. The notion of the return of all to a single source is very much a guiding logic for medieval thinking: there was a reason for the popularity of the tree model when placed in epistemic context, and for the interchange between tree and its branching cognates. M. 982 helps to dispel the notion that this model was unimaginative or unitary in its construction. As I have demonstrated, the riparian branch and its fellows are more capacious as complex metaphors than is initially apparent.

The image within M. 982 stands in for a reality veiled by invisibility; its aqueous and corporeal components, behaviours, structures, and qualities infuse the invisible with a specific set of behaviours. Through the accessible visual framework of Pierpont Morgan, M. 982, we are able to apprehend

${ }^{51}$ For a profitable comparison of elemental theory and Deleuzo-Guattarian rhizomatics, see David Macauley, 'The Flowering of Environmental Roots and the Four Elements in Presocratic Philosophy: From Empedocles to Deleuze and Guattari', Worldviews, 9 (2005), 281-314.

${ }^{52}$ Manuel Lima, Visual Complexity: Mapping Patterns of Information (New York: Princeton Architectural Press, 2011), p. 25.

${ }^{53}$ Philip Ball, Branches: Nature's Patterns, A Tapestry in Three Parts (Oxford: Oxford University Press, 2009), p. 130.

${ }^{54}$ Lima, Visual Complexity, p. 44. It is important to note that Visual Complexity is not the end point of Lima's thinking on the topic. See also Manuel Lima, The Book of Trees: Visualizing Branches of Knowledge (New York: Princeton Architectural Press, 2014).

${ }^{55}$ Gilles Deleuze and Félix Guattari, A Thousand Plateaus: Capitalism and Schizophrenia, trans. Brian Massumi (Minneapolis: University of Minnesota Press, 1987), p. 5. 
something of the mechanism of abstract image making in progress. Through the image-making process, we are able in turn to apprehend the specific affordances of water to the narration of the invisible. Furthermore, we can understand the manner in which diverse forms of ecological entanglement be they between body and world or between abstract entities - are joined by the bonds of typological likeness.

As a story of the relationship between human knowledge and its origin in divine knowledge, M. 982 maps out the terrain that defines medieval learning, and suggests the means by which knowledge can and should be approached. The historically distinct representation of knowledge evoked by M. 982 is best understood, I suggest, coupled with a schema that explores a complex cycle of cognition and hermeneutics. The amalgamation of medieval diagrammatology, personification allegory, and the imagery of hydrology presents something that plays upon many registers of medieval abstraction. As a diagram, M. 982 relates ideas to ideas by causal and teleological links, placing them in a hierarchy with distinct divisions. As a personification allegory, M. 982 participates in religious tropes surrounding the body as a point of interaction between human and divine.

Although the mapping of fluid properties onto the mechanism of a medieval diagram locks down the traits of water and prevents them from exercising their full freedom of expression, it nevertheless provides an opportunity to understand the role of water in medieval intellectual culture. The ecodiagrammatic flows within this article bring a sense of the distribution of cause and effect across hierarchies, the continuous transfer of flow, and the meandering force of rivers visible and invisible as they infuse the Arts with potency. For medievalists, a new facet of allegory is revealed: there is a hint within the diagram that divine mysteries have an ecology, that they are a larger environment with interconnections every bit as ordered and flexible as those found in nature.

The University of York 